\title{
"Min mormor er ikke vild med fodbold"
}

\section{Af Lone Friss Thing}

Kon bverken overskrides eller determineres $i$ sport. Kon er allestedsnarvarende $i$ sportens rum, men tillagges mangfoldige betydninger både fysisk, psykisk, socialt og kulturelt. Dette diskuteres ved en analyse af kønnede betydningslag $i$ danske elite sportskvinders levede erfaringer.

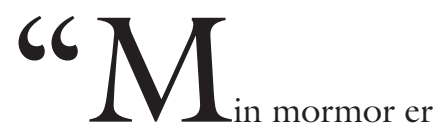

ikke vild med fodbold, det har hun vist aldrig været. Min stedfarmor synes også, at det er noget underligt fjollet noget. De siger det direkte til mig, de lægger ikke noget imellem. Min farmor siger, at jeg ødelægger mig selv. Og min mormor siger, at det bare er noget værre voldeligt noget. Så hun kan ikke forholde sig til det".

Mias beskrivelse af familiens fordomme over for hendes aktive fodboldliv viser aspekter ved de sociale forandringsprocesser i sport (Thing 1999). Det centrale fokus for nærværende artikel er danske sportskvinders kropsliggjorte erfaringer ${ }^{1}$ med ishockey, basketball og fodbold. De specifikke kropsbevægelser og emotionsudtryk, som kvinder udfører i fodboldkampens tacklingssituation og i skøjteløbet på ishockeybanen eller i angrebet i et fast break i basketballspillet, står i modsætning til de kropsbevægelser og emotionsudtryk, som kvinderne, ifølge deres egne udsagn, udfol- 
der i hverdagslivet. Denne problematik er omdrejningspunktet for artiklen.

Bolddiscipliner er sportsgrene, som i den internationale sportssociologiske forskning defineres som et kulturelt maskulint domæne (Elias og Dunning 1986, Messner 1992, Sabo og Messner 1994, Young og White 1995). Kvinder har dyrket sport gennem hele det 20. århundrede, men i de seneste tre årtier op mod årtusindskiftet har kvinders gennembrud i sport fảet en markant ny karakter. Antalsmæssigt er danske kvinders sportsaktivitet gennem de sidste 20 til 30 år blevet styrket. Flere kvinder dyrker sport end tidligere, og kvinder afstår ikke fra at dyrke sport, når de bliver xldre (Fridberg 2000).

\section{Metode}

Det empiriske materiale i artiklen bygger på interview med 26 unge boldspillende kvinder i alderen 15 til 30 år. Undersøgelsen indbefatter også et feltstudie af tre kvindehold fra de danske eliteniveauer i fodbold, basketball og ishockey. Jeg fulgte to klubhold og et landshold til deres daglige træning og til kampe i en periode, der forløb over halvandet år.

I interviewene blev kvinderne spurgt om, hvorledes de begyndte at spille bold, og om hvilken betydning, boldspil havde for dem. Interviewets tema var kvinders erfaringer med det aggressive spil inde på banen $\mathrm{i}$ et forsøg på at finde ud af, hvorfor kvinder dyrker sportsgrene, som indeholder handlingsmomenter, som ud fra en hverdagsforståelse er svære at forbinde med 'kvindelighed'. Samtalerne handler primært om konkrete spilbegivenheder. Tanken er at fă kvinderne til at tale om de observerede begivenheder. Der skelnes således mellem generelle udsagn og konkrete levede begivenheder i forsøget på at komme tæt på de virkelighedsnære kropslige spilhændelser. Metoden er inspireret af den social fænomenologiske forskningstradition ved Giorgi (1985), Kvale (1997), Denzin (1984) og Polkinghorne (1988).

\section{DEN KØNNEDE SPORT}

Feltarbejdet i boldspilskulturen viste, at sport ikke er en kønsneutal zone - hverken ude eller inde på banen. ${ }^{2} \mathrm{Nu}$ til dags dyrker kvinder alle tænkelige sportsdiscipliner. I 1972 blev kvindefodbold en officiel disciplin i Danmark. I sæsonen 1973 begyndte tre danske klubber med kvindeishockey. Det var klubberne Rungsted, HIK (nu IC Gentofte) og Herlev. Danske kvinder har deltaget i basketball siden DBBF's etablering i 1950'erne. Kvinder har gradvis fået mulighed for at dyrke sport, som primært har været dyrket af mænd. Selvom kvinder, der dyrker de nævnte boldspil, er minoritetsgrupper set $\mathrm{i}$ forhold til antallet af mandlige deltagere, så symboliserer de en ny historisk tendens og et nyt socialt fænomen. Hvad angår fodbold, har kvinders deltagelse i de sidste 30 år internationalt set udviklet sig eksponentielt til i dag at rumme 30 millioner registrerede deltagere (Cox og Thompson 2000). I et tvær-kulturelt sociologisk studie af kvindefodbold fra henholdsvis Norge, England, Tyskland og Spanien, som er udført af fire kvindelige professorer, viser det sig, at kvindefodbold er en af de hurtigst voksende sportsgrene i verden (Scraton et al. 2000). I Norge er kvindefodbold blevet den største sportsdisciplin for kvinder med hele 64.000 deltagere. I Danmark er tallene beskedne. Danmark har ca. 44.000 fodboldkvinder, ca. 3900 basketballkvinder, og ca. 426 kvinder er aktive ishockeyspillere (DIF 2001). Kvinders idrætsdeltagelse i boldspil repræsenterer en sport i forandring og er samtidig et udtryk for feminine identitet(er) i forandring. Men trods det, at kvinders indtrxden i de traditionelt set 'maskuline' sportsgrene, som henholdsvis ishockey, basketball og fodbold, har fået en fremvækst både nationalt og internationalt, så er kvinders deltagelse $\mathrm{i}$ disse sportsgrene ikke en helt ny ting. Allerede i 1887 eksisterede en fodboldklub for velstillede kvinder. Dengang spillede kvinderne i en baggård i København (Bonde 1991, 160). Kilderne fortæl- 
ler yderligere, at enkelte kvinder i 1899 spillede boldspil i København i et indelukket eksercerhus på Kastellet. Det foregik ikke på de samme åbne og skue-værdige pladser som mænds aktiviteter, men derimod i kulissen. Ottesen (1986) skriver således, at nogle kvinder i 1906 ansøgte de to klubber $\mathrm{B} 93$ og $\mathrm{KB}$ om lån af deres fodboldbaner. Kvinderne fik afslag, dog fik de ikke et kategorisk afslag, men et tilbud fra KB's ledelse om en spilleplads kl. 6 om morgenen. Og med krav om at udsætte kvindelige vagtposter til at holde eventuelle mandfolk på afstand. Kvindekroppen blev ifølge datidens normer ikke offentligt hyldet, men nok udfoldet til glæde for kvinderne selv.

Pedersen $(1999,64)$ advokerer i artiklen "Forsvinder kønnets betydning i den excellente præstation?" for, at kønnets betydning forsvinder i elitesportens konkurrencesituation. Pedersen har sandsynligvis ret i sin antagelse om, at kønnets fysiske beskaffenhed (eller nærmere fordomme om kvindekroppens fysiske beskaffenhed) transcenderes i selve konkurrencesituationen, men sportens social- og kulturhistoriske begivenhed er en kontekstuel ramme, som ikke overskrides i alle former for moderne sport. Lad mig give et eksempel. ${ }^{3}$

I sportsgrene som traditionelt har været dyrket, præget og styret af mænd, både rekruteringsmæssigt, magtmæssigt og ideologisk, er der kønskonnotationer, som har betydning i en sociologisk analyse af sportssituationsrum. Det er derfor vanskeligt at sætte en definitiv parentes om kønnet (Pedersen 1999, 73). Det sociale og kulturelle rum som sport er, og den sociale og kulturelle konstruktion som køn er, mener jeg, er svær at overse og ligeledes meget svær at adskille. For sport er historisk-, kultureltog socialt set et konstrueret 'maskulint' univers. Pedersen kan have ret i påstanden om, at nogle kvinder har behov for at nedtone kvindekønnet i et enkønnet (maskulint) univers som sport. Men den transcendentale bevægelse ‘ud af kvinden' og 'ind i sporten' er ikke altid enkel. I nogle sportsdiscipliner kan køn og kønsrelationerne i sig selv være drivkraften bag sportsdeltagelse, forstået på den måde, at indtræeden i en allerede defineret maskulin kultur, som for eksempel ishockey eller fodbold, kan være et forsøg på, og en kropslig manifestation af, at sætte kønsforståelserne og kønsrelationerne i spil. Ishockeyspillende damer møder sportskulturens maskuline køn anderledes end kvinder, der deltager i sportsgrene så som gymnastik og dans, som traditionelt set har været forbeholdt kvinder. Sport er ikke en enhedskultur. Moderne sport er en differentieret størrelse, og vi må være åbne over for tanken om et kønsperspektiv i analysen af sport.

Kønnet som 'baggrund' (Moi 1999b) eller 'forgrund', for nu at trække på det fænomenologiske perspektiv som Moi drager nytte af, er derfor altid allestedsnærværende. Køn i sport træder i karakter på forskellige tidspunkter og på alsidige måder og er ikke nødvendigvis en overskridelse af køn, hverken fysisk, socialt eller kulturelt. Denne påstand vil jeg sandsynliggøre med udsagn fra unge kvinder, der dyrker sportsgrene, som ikke har været forbundet med kvindelighed. Den hermeneutiske fortolkning af de sportslige erfaringer tager udgangspunkt i de konkrete kropsbevægelser og emotionskvaliteter på boldspilsbanen.

\section{SPORTKVINDER DESTRUERER MYTER}

Kulturens køn i fodboldklubbens klubhus er ikke til at tage fejl af. Øl, musik og fjernsynstransmission af 'bare damer' midt på formiddagen og salg af skumbamser og cigarer i kioskbaren tegner konturerne af en traditionel 'maskulin' atmosfære. Men i al klubbens traditionsrige mandehørm sidder børn på skødet af mødre, som er kommet for at se deres xldre fodboldspillende afkom, de unge piger/damer, der står klar i fodboldstøvlerne. De omkringløbende børn, de fremmødte forældre og kvindespillerne selv ænser åbenlyst ikke, de for en 
kvindelig forsker i felten, relativt provokerende tv-reklamer en tanke. Kulturens køn bliver ikke problematiseret eller fremhævet som en byrde af de boldspillende kvinder. Ved andre observationer lægger jeg mærke til, at elitekvinder på klubhold ofte må vige for drengespillere i kampen om de gode lysbaner i de sene efterårsaftener (Thing 1999). I basketballklubben harcelerer kvindespillerne over, at det altid er kvinderne, der skal skrabe penge sammen til klubben, men at det er mændene som pengene bliver brugt til. Ovennævnte beskrivelser af den kønnede atmosfære i klublivet rundt om i det danske landskab, indfanger nogle af de sociale og kulturelle betingelser - barrierer og ressourcer - som er sportkvinders vilkår. I forbindelse med de sociale handlinger inde på banen i kampbegivenheden kommer kønnet som social- og kulturel handling også i tale. Det er derfor pointen, at konteksten for sportsbegivenheden ikke kan tænkes løsrevet fra de sociale handlinger, som foregår inde på banen - de er mere præcist relationelt beslægtede. I de kommende empiriske afsnit vil jeg illustrere, hvorledes forholdet mellem det maskuline og det feminine italesættes i den danske boldspilsskontekst. ${ }^{4}$ Formålet er ikke at reproducere kulturelle stereotypier, men at vise hvorledes køn i nutidens sport til stadighed skabes i forhold til to kønslinier.

\section{RELATIONER TIL DRENGENE OG TIL 'DET MASKULINE'}

Rosa er tidligere elite kunstskøjteløber, men skiftede karriereforløb til ishockey på grund af uoverensstemmelser med træneren. Hendes far er engageret i ishockey, og da hun har tilbragt meget af sin opvækst i ishallen, begynder hun i stedet for kunstskøjteløb at spille ishockey. Om forholdet til ishockeydrengene, som Rosa nu er sportskollegaer med, siger hun:

"Det er også fordi, jeg er kommet ind i ishockeyklubben, at selve forholdet til de dren- ge der går oppe i skøjtehallen er absolut blevet mere afslappet. Hvor før der krøb jeg langs væggen, hvis jeg så en ishockeyspiller (en dreng), nu er det mere”

Rosa bliver gradvist involveret $\mathrm{i}$ ishockey og er nu landsholdsspiller. Hendes dybe kendskab til både traditionel kvindesport og mandesport gør hendes udtalelse interessant for en videre analyse. Rosa betoner, at relationen til drengene er afslappet nu, hvor hun selv spiller ishockey. Relationerne er blevet af-dramatiseret og af-traditionaliseret. Det ser hun som positivt og som en kvalitet og ikke, som man kunne tro, en form for ukønnet androgyni eller af-seksualisering af kønsforholdet, tværtimod. $\mathrm{Nu}$ er der en relation, før var der afstand mellem kønnene. I hendes forståelsesramme og i hendes liv levede kønnene tidligere hver deres separate liv i ishallen.

Mia har altid spillet fodbold med drengene $\mathrm{i}$ frikvarterene og har altid godt kunne lide det. Hun uddyber relationen til drengene i sin opvækst og forklarer ydermere, hvorledes hun oplever det at være en pige med interesse for fodbold:

“Nej men folk kan jo ikke forstå det. Altså jeg har jo spillet, jeg har spillet altid, mens jeg har gået i skole, og altid mødt det (forundringen) blandt mine pigeveninder. De kan jo ikke forstå, at hvis drengene skulle ud og spille fodbold, i idrætstimerne eller i gymnasiet...hvis drengene skulle ud og spille fodbold, så var jeg også ude og spille fodbold. Og det var jo hver gang, sådan noget kan de ikke forstå”.

Mias forældre har ikke udtalt sig konkret om hendes sportsinteresse. De har aldrig påtalt den. Hun mener dog selv, at forældrene var chokeret over hendes fritidsinteresse.

Henriette som også er fodboldspiller siger:

"Det var jo nok meget atypisk, men altså det var meget naturligt for mig. Det er først sådan nu, jeg kan se, at det virkelig var meget 
atypisk for en pige at gøre det, ikke. Men jeg kan huske, at senere da jeg kom på fritidshjem, der var jeg utroligt drenget, spillede fodbold med drengene, kørte gokart, altså det var ikke særligt typisk piget”.

\section{Rosa siger:}

"Jeg ser ikke ishockey som en mandesport, hvis, så var jeg ikke kommet her. Nej, det er sport, sport, det er sport. Det er intensiteten, glæderne. Og måske lyder det mærkeligt, men i en hård sport som denne, kan jeg realisere mig selv - det tror jeg, at jeg kan $i$ ishockey".

For Rosa er ishockey ikke en mandesport. Hun føler en form for selvrealisering $\mathrm{i}$ ishockey, men alligevel er det ikke uproblematisk for hende at krydse kønsbarrieren. Selvom hun ikke opfatter ishockey som en mandesport, problematiserer hun kroppens feminine udtryk. Hun er maskulin på banen og i bevægelserne, men hun er feminin, når hun har taget sine skøjter og sit udstyr af. Væegttræningen som træneren kræver, vælger hun at udføre uden de tunge vægte. Hun omgår med andre ord vægttræningen og benytter sin egen kropsvægt som naturlige vægtstænger $\mathrm{i}$ håbet $\mathrm{om}$, at træningen ikke resulterer $\mathrm{i}$ en stor og tung mandekrop.

Sandra, som er fodboldspiller, adskiller sig fra ishockeyspilleren Rosa. Sandra giver følgende fortælling om sit liv i fodboldkulturen:

“Da jeg kom i 4. og 5. Klasse, så sad jeg (pause) - "nej altså nu må du tage dig sammen". Fordi selv om man spiller fodbold kan man godt have....så begyndte jeg at have langt hår, så kom det stille og roligt”.

Sandra benævner sig som drengepige. Hun spiller fodbold med drengene og nyder de aktive udendørsaktiviteter, men fodboldspillet blev et problem for hende, da hun nærmede sig puberteten. Ved at lade sit hår gro fra at være kortklippet til at blive en lang blondt hårpragt, håndteres kvindeligheden således, at identiteten ikke karambolerer med fodboldspillet på banen og hendes (hetero)sekualitet uden for banen. Det lange hår er hendes tegn på femininitet, et tegn, som hjælper med at bearbejde uoverensstemmelsen, der er forbundet med at være kvinde og fodboldspiller. Følelsen af ikke at være som majoriteten eller følelsen af ikke at passe til kvindeidealerne uden for sporten er temaer, som flere af boldkvinderne fremhæver. Sofie siger:

"Jeg behøvede nogle spillere som jeg kunne bruge min styrke i forhold til. Uden at føle at nogen kom til skade. Det var meget oplagt, at jeg skulle tage hensyn altid. Jeg ved ikke, men når du er en pige, og når du er stor, har du tilbøjelighed til at "holde på dig selv", til at kontrollere dig, i stedet for bare at spille godt".

Sofie taler her om selve spilhandlingerne inde på banen. Citatet stammer fra hendes oplevelse af at få lov til at spille med drenge/mænd. Hun er en meget høj kvinde, som gennem tiden har følt, at hun burde lægge kropslige bånd på sig selv for ikke at genere andre kvinder. I spillet med mændene bevæger hun sig frit og ubegrænset. Udtalelsen ligner andre spilleres antydninger af, at kropshandlingerne og det emotionelle liv i sport muliggør udfoldelse, som ikke findes i andre institutioner. Anne siger eksempelvis:

“Du får lov til at leve en hel masse følelser ud i sporten, som du ikke har plads til, og som ikke er legitimt i den almindelige hverdag (humoristisk tale). Det er jo både glæde og skuffelse og aggressivitet, ja, alting. Du får lov til at leve det på et meget større felt, end du gør i din hverdag. Jeg synes i hvert fald, at lige pludselig kan man tillade sig at sætte sig ned og tudbrøle over et eller andet, som er fuldstændig vanvittigt - og hvornår kan man gøre det? Men når det er i sport, så er det i orden". 


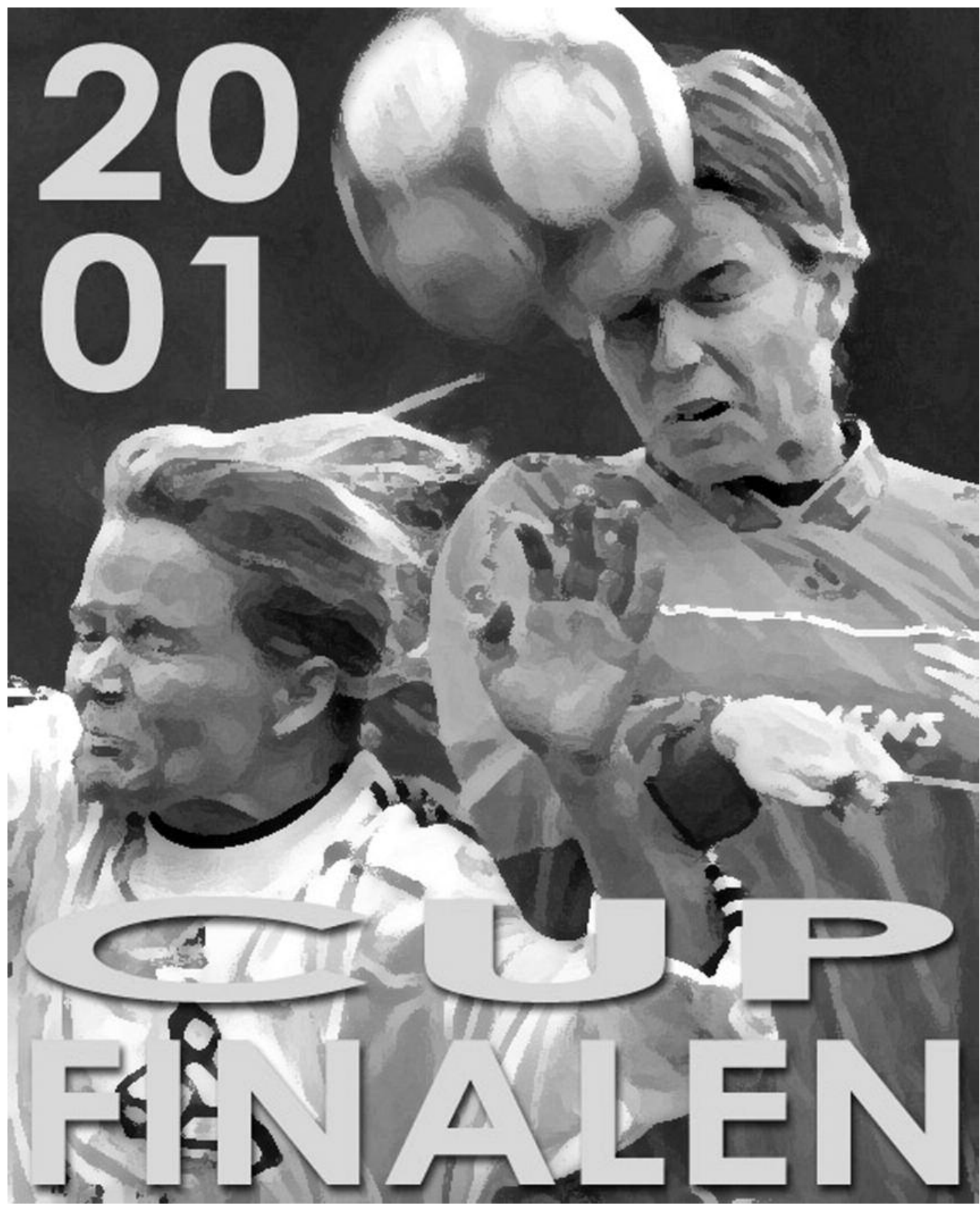

Tak til Topp-serien. 
'Det maskuline' i sporten italesættes i samtalerne med ord som: At få blå mærker, at blive snavset, at lege vilde lege og at give sig fuldt ud. Undersøgelsen viser, at boldspil ofte beskrives som 'maskulint' af kvinderne. Til mit uddybende spørgsmål i afhandlingen om, hvordan de to kulturelle/ sociale kønskategorier, 'det maskuline' og 'det feminine', strukturerer erfaringerne, konkluderer jeg, at kønskategorierne er virksomme i identitetsskabelsen og i forståelsen af boldspil. Kvinderne forhandler kvindeligheden relationelt. Den sportslige selvforståelse skabes mellem to kønslinier. I samtalerne benyttes kønskategorierne som fortolkningsressourcer til at forstå sportslivet. Kategorierne udelukker hinanden, men benyttes på forskellig vis til at skabe komplekse billeder af kvinder i sport.

\section{LEGEN MED GRIMHEDEN OG DET VOLDSOMME}

Bente Rosenbeck (1998, 132) fremhæver, at kvinderne $\mathrm{i}$ feminismens anden bølge $\mathrm{i}$ 1970'erne gjorde op med skønhedsmyten gennem en legemliggørelse af grimheden. Grimheden bestod $\mathrm{i}$ at frasige sig datidens kvindelighedsattributter, og ved rødstrømpeaktioner blev bh, ballonbryster og paryk kastet i en skraldepose. Det at benytte grimheden på en symbolsk måde i kampen mod kvindelighedens forbundethed med krop og biologi, giver sportskvinderne også udtryk for $\mathrm{i}$ interviewene. Men den benyttede grimhedssymbolik i sport kan ikke siges at være politisk, snarere emotionel og praktisk. I boldspil er der mulighed for at lege og spille med grimheden, voldsomheden og de tabuiserede følelser. For en stund afskrives de traditionelle kvindelige dyder. Ishockeypiger udtaler, at jo mere ucharmerende ishockeyspillet fremtræder jo bedre. Ishockeyudstyret, hjælm, visir og skulderpuder hjælper denne proces. Fodboldspilleren Rikke uddyber det med grimheden og fremhæver det positive ved, at fodbold foregår udendørs:
"Det er det der med, at piger skal ud og træne i mørke, der ligger vandpytter på halvdelen af banen...altså du kommer møgbeskidt ind igen. Jo, altså, det er det der med at blive tacklet hårdt i en fodboldkamp. Jeg synes også stadigvæk fodbold et eller andet sted, jamen det er mere maskulint end... sådan som jeg ser det".

En anden spiller siger eftertænksomt:

"Det kan jeg godt lide, det der med at man har været ude og give sig selv. I nogle situationer hvor du virkelig har, altså løbet fra den ene ende af banen til den anden. Du jagter den anden - "nu skal du bare hjem og forsvare, og hun er to skridt foran dig, og du skal bare hjem, og hun skal ikke have lov at komme ned i den anden ende før dig”. Sådan nogle ting, det kan jeg godt lide".

Kropsbevægelserne, som de boldspillende kvinder udfolder på sportsarenaen, forstærker ikke etablerede former for femininitet, som undersøgelser af for eksempel aerobics viser (Maguire og Mansfield 1998). I aerobickulturen skabes kvindekroppen i forhold til standarder for femininitet. Aerobicsudøvere fremhæver vigtigheden af, at kroppen præsenterer sig som værende slank, muskuløs og kontrolleret. Mulighederne for at bevæge sig kropsligt og kraftfuldt og mulighederne for at udtrykke aggressivitet og intensitet i en fælles kamp om at vinde, er centrale omdrejningspunkter i boldspil. Spillerne fokuserer ikke på kvindekroppens form, udtryk eller udseende, når de spiller. Analysen viser derfor, at boldspilsaktiviteten er en episodisk, kropslig og emotionel positionering, hvor traditionelle forestillinger om køn afmystificeres eller omformes. Boldkvinder nedbryder kønsnormerne i sport, selvom de ikke er ønskede af mændene i klubben, og trods det, at praktikken, ifølge deres egne udsagn, anses som værende en for kvinder afvigende aktivitet, ofte både internt i familierne og af det omkringliggende samfund. 


\section{AfSLUTTENDE BEMÆRKNINGER}

Udfordringer og forandringer i senmoderniteten skal findes i forholdet mellem kønnene. Der er sket forandring i kvinders uddannelsesniveau (Beck 1997). Unge kvinder har i forhold til deres mødre og bedstemødre mere frihed, hvad angår ret, uddannelse og seksualitet. Trods det faktum, at social ulighed mellem kønnene stadigvæk eksisterer, også i sport, har den sociale ulighed alligevel skiftet karakter (Beck 1997, 131). Jeg mener således, at individualiseringsprocesser ${ }^{5}$ også afspejles i fritidslivets sport. Kvinders højnede uddannelsesniveau, brede deltagelse på arbejdsmarkedet og omstruktureringen af livssammenhænge, det som Beck kalder en (omend relativ) frisættelse fra modernitetens halvfeudale forsørgelse, har banet vejen og medført, at kvinder i Danmark har fået mulighed for at realisere et fritidsliv, der er styret af lyst og interesse. Interviewene viser, at familiesituationen forhandles således, at det for nogle kvinder er muligt at dyrke sport flere gange om ugen og også bruge adskillige timer hver weekend på at spille elitesport, om end de xldre generationer i familien har svært ved at acceptere forandringerne.

De interviewede kvinders erfaringer med boldspil udtrykker lyst og interesse for kraftfulde og konfronterende kropslige handlinger, for emotionel spænding og for den mimetiske leg, der opstår i kampsituationen. Hvor traditionelle kvindeidrætter, så som aerobics og gymnastik, i højere grad fokuserer på kroppens form og udseende og den æstetiske koordination. De kvindelige boldspillere i undersøgelsen fremhæver lysten til at bryde med de etablerede normer for "feminin kropslighed". Analysen peger derfor på boldarenaen som en kropslig frizone, som et sted, hvor kroppen får forrang, men hvor kroppen ikke tænkes som afgrænset eller begrænset, ej heller som smuk, attraktiv eller formbar, men som magtfuld, brugbar og legende. Den kropslige frizone erfares ikke ens af alle sportskvinder. Sportskvinders identitetsformer er differentierede. Empirien viser, at den heteroseksuelle unge kvinde (Rosa), der uden for sportsbanen tilskriver sig traditionelle kvindelige attituder, nyder sportens rum som et brud med selvsamme kvindelighed. Hun betegner ishockeysporten som værende maskulin, men ikke som en aktivitet udelukkende for mænd. Henriette, der til daglig betegner sig som drengepige, nyder sportens rum som et frirum fra den daglige stigmatisering. Den høje og muskuløse sportskvinde (Sofie), der gennem sin opvækst har erfaret sig som 'anderledes', alene qva sin kropstørrelse, erfarer sporten og spillet med drengene som et frirum, som et sted hvor hun ikke begrænser kropsligheden. På banen og i træningssituationen med drenge kan hun give de kropslige kompetencer frit løb. Den lave ishockeyspillende Anne ser ligeledes sporten som et frirum, hvor hun udfordrer kropsligheden. Erfaringerne fremstår derfor som alsidige billeder, men de billeder, som skabes af køn på boldbanen, må relateres til de billeder af køn, som eksisterer uden for banen. Fortolkningerne af kvindernes aktiviteter, også de sociale handlinger på banen, kan ses i et kønsperspektiv. Jeg tror derfor ikke, at man kan konstatere, at køn overskrides i elitesport. Sport er derimod et kønsscenario af rang. I stedet for at tale om overskridelse af køn i sport, kunne vi snarere tale om indskrivning af køn i sport, hvor indskrivningen sætter spor på forskellig måde. Fodboldspil er ikke kun fodboldspil, men en disciplin, som formidler kønskulturelle traditioner. Kvindefodbold konfronterer både udøverens og tilskuerens kønsforståelse, fordi vi er 'kastet' ind i en ganske bestemt kulturhistorisk periode, hvor fodbold i mere end hundrede år har været forbundet med maskulinitet. Og det at bryde med vanens magt, med de etablerede traditioner i boldspil, sætter kønsforståelserne i spil. 


\section{NOTER}

1. Med erfaring henvises ikke til essentialistisk tænkning, hvor kropslige erfaringer defineres biologisk. Kvindelige erfaringer tænkes fænomenologisk, de skabes i den levede realitet som altid er situationsbundne og dermed socialt, kulturelt og historisk betingede (Moi 1999, 71-76).

2. Distinktionen mellem på og uden for banen er vigtig. Analyser af spilpraksis på banen i kampsituationen er sjaldent belyst (Thing 1999), og det er med glæde, jeg kan konstatere, at Lars Tore Rongland (2000) med sin doktorafhandling: "Gjennom sesongen. En sociologisk studie av det norske kvinnelandslaget i håndball på og utenfor banen", fastholder distinktionen.

3. Heideggers og Ponty's eksistentielle fænomenologi bryder med Husserls transcendentale fænomenologi, hvor objektivitet er funderet i det erfarende subjekt. Ponty viser (1989) netop i Phenomenology of Perception, at det er den levede krop snarere end det transcendentale ego, der organiserer erfaring. Livsverden er en baggrundshorisont som virker i de kropsliggjorte forståelsesmåder, vi som mennesker praktiserer. Jeg mener derfor ikke, at de historisk- og kulturelt betingede horisonter som sådan kan transcenderes, da de er indkorporeret i praksis, og altid, men på forskellig måde, vil engagere sig i menneskets-væren-i-verden (Hyldgaard 1990 og Moustakas 1994).

4. Det maskuline og det feminine ses som en social konstruktion. Men jeg skelner i artiklen ikke begrebsligt skarpt mellem det maskuline/det mandlige og det feminine/det kvindelige, da jeg ikke mener, en sådan opdeling er funktionel. Mandelighed og kvindelighed er også socio-kulturelle konstruktioner.

5. Beck $(1997,128)$ forstår ikke individualisering som voluntaristisk tænkning, hvor individet har frit valg $\mathrm{i}$ alle livets forhold. Individualisering forstås i forhold til sociale forandringsprocesser, som skift i livssammenhænge og i de biografiske mønstre, dvs. både på et struktur niveau (objektive forhold) og på et subjektivistisk niveau (ændringer i bevidsthed og identitetsprocesserne). Individualisering sker som en frisættelse fra traditionelle bindinger så som familie, religion, lokalitet, klasse, men blot for at blive ført af nye strukturerende mekanismer så som arbejdsmarked, økonomi og institutioner (herunder også sport).

\section{LITTERATUR}

- Beck, U. (1997): Risikosamfundet. På vej mod en ny modernitet. Hans Reitzels Forlag, København.

- Bonde, Hans (1991): Mandighed og sport. Odense Universitetsforlag, Odense.

. Cox, Barbara og Thompson, Shona (2000):

"Multiple Bodies: Sportswomen, Soccer and

Sexuality", in Int. Rev. For the Soc. of Sport. vol.

35, no.1. pp: 5-20.

- Denzin, N. K. (1984): On Understanding Emotion. Jossey-Bass Publishers, San Francisco.

- Elias, N. \& Dunning, E. (1986): Quest for Excitement.. Sport and Leisure in the Civilizing Process.

Basil Blackwell, Oxford.

- Fridberg, Torben (2000): Kultur-og fritidsaktiviteter 1975-1998. Socialforskningsinstituttet, København.

- Giorgi, A. (Ed.) (1985): Phenomenology and Psychological Research. Duquesne University Press, Pittsburg.

- Hall, A. M. (1996): Feminism and Sporting Bodies. Human Kinetics, USA.

- Hyldgaard, K. (1990): Heidegger og teknikkens tidsalder. Aarhus Universitetsforlag, Aarhus.

- Kvale, S. (1997): Interview. En introduktion til det kvalitative forskningsinterview. Hans Reitzels Forlag, København.

· Maguire, J. \& Mansfield, L. (1998): “No-Body's Perfect": Women, Aerobics, and the Body Beautiful", in Sociology of Sport Journal, 15. pp: 109-137. - Merleau-Ponty, M (1989): Phenomenology of Perception. Routledge, London.

- Messner, M.A. (1992): Sport and the Problem of Masculinity. Power At Play. Beacon Press, Boston. - Moi, Toril (1999): What is a Woman?. And Other Essays. Oxford University Press, New York.

- Moi, Toril (1999b): “"Jeg er kvinde”. Kroppen som baggrund i "det andet køn", in Kvinder Køn \& Forskning, 2/1999, København.

- Moustakas, Clark (1994): Phenomenological Research Methods. Sage Publications, London.

- Ottesen, Laila (1986): "Damefodbold: pigespil og kvindekamp”, in Idratshistorisk Årbog, 2.årg., Dansk Idrætshistorisk Forening. Krop og kultur, Viborg.

- Pedersen, Inge Kryger (1999): "Forsvinder kønnets betydning i den excellente prestation?", in Kvinder, Kon \& Forskning, 4/2001.

- Polkinghorne, D.E. (1988): Narrative Knowing and the Human Sciences. State University of New York Press, Albany.

- Ronglan, Lars Tore (2000): Gjennom sesongen. En sociologisk studie av det norske kvinnelandslaget $i$ håndball på og utenfor banen. Dr. Scient. Avhandling. Norges Idrettshøgskole, Oslo. 
- Rosenbeck, Bente (1998): "Konstruktion af kvindelighed", in "Socialkonstruktivisme. Bidrag til en kritisk diskussion", in Järvinen, M. og Bertilsson, M. (eds). Hans Reitzels Forlag, København. - Sabo, D. \& Messner, M. (1994): Sex, violence and power in sports. Crossing Press, USA.

- Scraton, Sheila; Fasting, Kari; Pfister, Gertrud og Bunuel, Ana (1999): “It's Still a Man's Game? The Experiences of Top-Level European Woman Footballers", in Int. Rew. For the Soc. of Sport. Vol.34, no. 2. pp: 99-111.

- Thing, Lone Friis (1999): Sport - en emotionel affare. Kvinder, holdsport og aggression. Sociologisk Institut, København.

. Young, K.; White, P. (1995): "Sport, Physical Danger, and Injury: The Experiences of Elite Woman Athletes", in Journal of Sport and Social Issues. 19: 45-61.

\section{SUMMARY}

This article is a sociological analysis of young Danish female ballplayers' sports experiences. The empirical investigation includes 26 interviews with elite sports women and fieldwork inquiry in specific clubs. The main focus is on the players' experiences of ballgames and on the construction of gender round the lines of masculinity and femininity. Body contact, emotions and play phenomena are revealed as the essential elements of sports such as soccer, ice hockey and basketball, also for women. Finally the article discusses how the social change in sport can be seen in relation to changes in society in general. The article concludes that sport is a differentiated institution and that a gender perspective is needed in the analysis of sporting identities.

Lone Friis Thing, ph.d., forskningsadjunkt ved Sociologisk Institut og ekstern lektor ved Institut for Folkesundhedsvidenskab, KU 